\title{
ラドン測定器の校正及びラドン研究に関する 英国公衆衛生庁（PHE）訪問記
}

真田哲也, 反町篤行

（227頁をご覧ください）

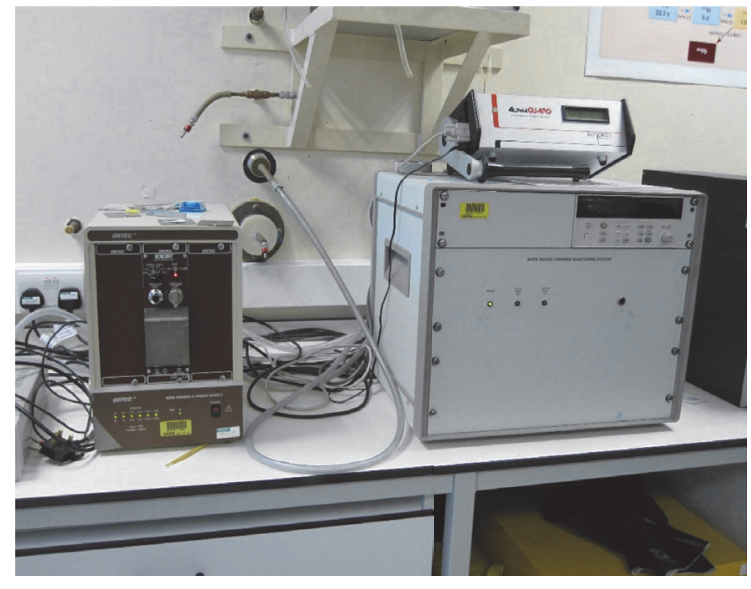

Fig. 5 大型ラドン標準場のラドン濃度及びラドン 壊変生成物濃度測定のための装置

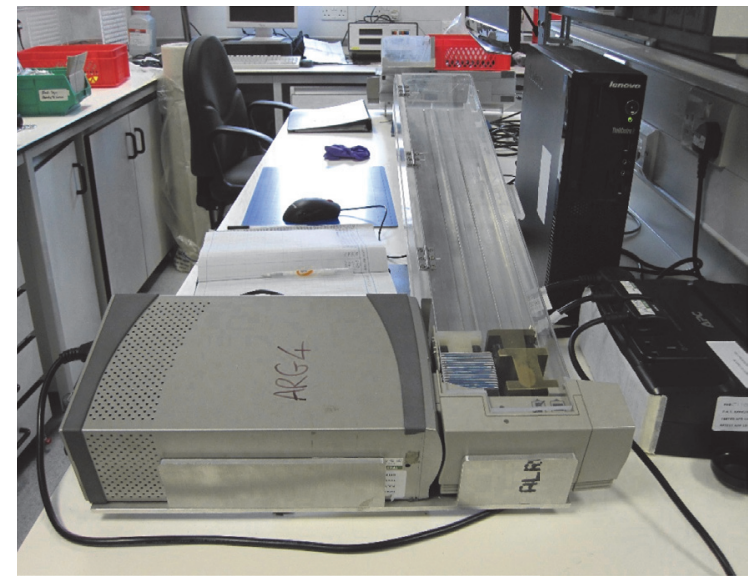

Fig. 9 エッチング後, CR39 フィルム上に生成し たエッチピットを計数する自動計数装置

\section{水晶体の放射線防護に関する専門研究会追加報告（I）}

一わが国における水晶体線量評価に関する研究と

\section{原子力発電所の線量管理の現状一}

赤羽恵一, 飯本武志, 伊知地猛, 岩井 敏, 大口裕之, 大野和子, 加藤昌弘, 川浦稚代, 黒澤忠弘, 立崎英夫, 辻村憲雄, 浜田信行, 林田敏幸, 堀田 豊, 山崎＼cjkstart直，横山須美

（249頁をご覧ください）
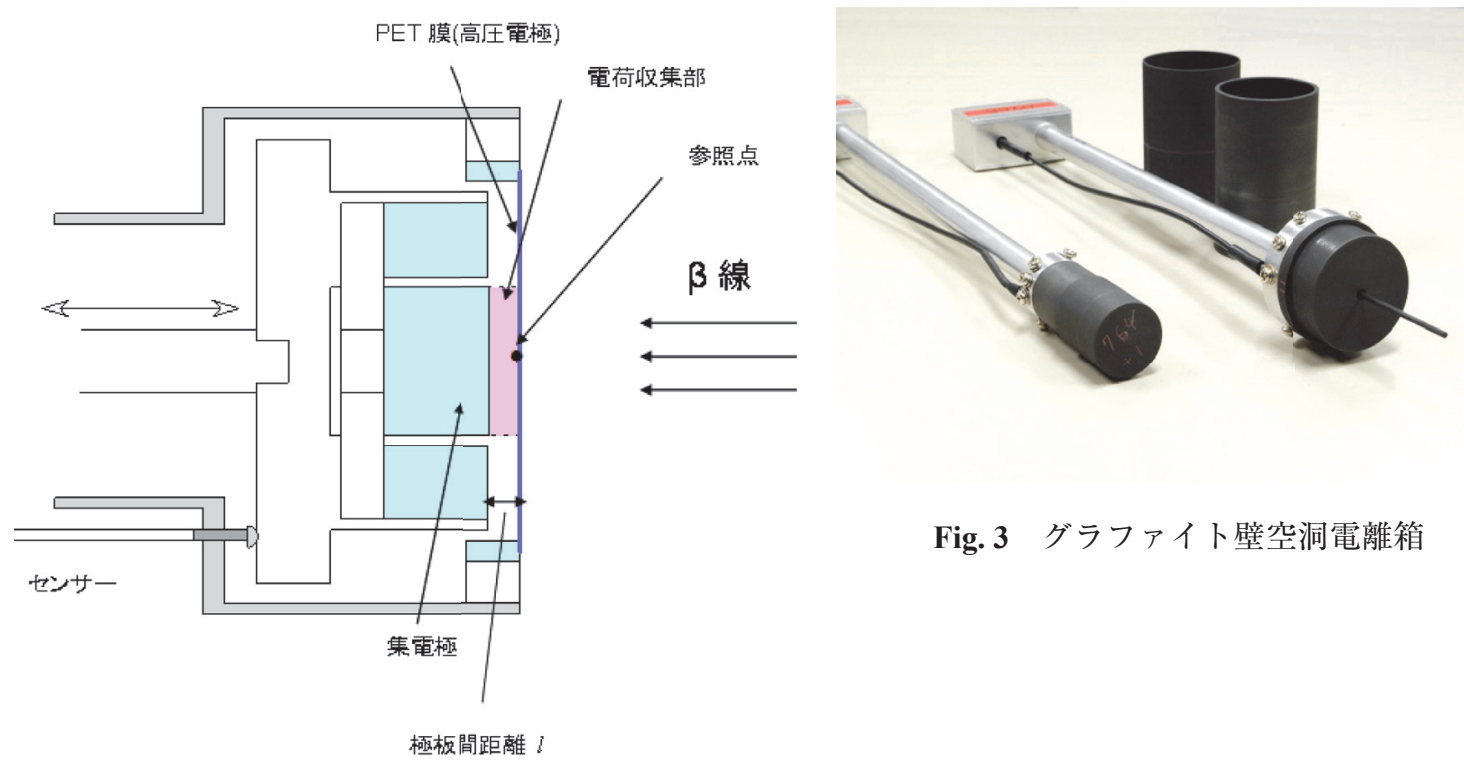

Fig. 3 グラファイト壁空洞電離箱

Fig. 1 外挿電離箱の概要図 